\title{
KEKUATAN YURIDIS PERSUMPSION DALAM PROSES PEMBUKTIAN PERKARA
}

\author{
M. Aunurrofiq Dsn. Kepatihan RT.04 RW.03 \\ Nour_sie@yahoo.com Tulangan Sidoarjo
}

\begin{abstract}
This article discusses judicial strength of judge's presumption in the examination process according to Islamic law of criminal procedure and Indonesian code of criminal procedure. Since there are numerous motive of crime nowadays, judges must always follow procedure and have sufficient legal knowledge in the examination process to ensure just verdicts. In the process, judicial presumption play crucial role but it must be based on evidence according to Indonesian code of criminal procedure. Similarly, in Islamic criminal procedure, presumption is important to be basis of verdict as long as supported by other evidence. The difference is that presumption in Indonesian code of criminal procedure can only be considered as indirect evidence, whereas is Islamic criminal procedure, it can perform as direct evidence. Thus, the use of presumption in examination of criminal cases depends on the judges' wisdom.
\end{abstract}

Keywords: Presumption, Islamic law of criminal procedure, Indonesian code of criminal procedure.

Abstrak Artikel ini membahas tentang kekuatan yuridis persumpsion hakim dalam proses pembuktian perkara menurut Hukum Acara Pidana Islam dan KUHAP. Kekuatan yuridis persumpsion, menurut KUHAP, baru bisa mempunyai kekuatan hukum untuk menjatuhkan putusan jika dikaitkan dengan alat bukti yang lain. Kekuatan yuridis persumpsion menurut Hukum Acara Pidana Islam, sudah mempunyai kekuatan hukum untuk menjatuhkan putusan meskipun tanpa didukung oleh alat bukti lain. Persumpsion dalam KUHAP dan Hukum Acara Pidana Islam keduanya mempunyai kesamaan, yakni sama-sama dapat digunakan sebagai alat bukti dan mempunyai kekuatan hukum dalam proses pembuktian, sedangkan yang membedakan adalah KUHAP berlaku pada pembuktian tidak langsung sedangkan dalam Hukum Acara Pidana Islam berlaku pada pembuktian langsung. Sedangkan kelebihan serta kekurangannya tergantung kepada hakim, apakah ia mampu menggunakan persumpsion dengan arif dan bijaksana atau tidak dalam menangani, mengadili dan menjatuhkan putusan.

Kata Kunci: Persumpsion, pembuktian perkara, Hukum acara pidana Islam, KUHAP. 


\section{Pendahuluan}

Suatu kenyataan hidup bahwa manusia itu tidak sendiri, dirinya hidup berdampingan bahkan berkelompok dan selalu mengadakan hubungan antar sesamanya. Hubungan yang terjadi berkenaan dengan kebutuhan akan hidupnya, tidak mungkin selalu dapat dipenuhi sendiri, sebagaimana ditegaskan oleh Aristoteles sebelum abad masehi bahwa manusia adalah makhluk sosial (Zoon Politicon). ${ }^{1}$

Satu keadaan yang tidak dapat dihindari tatkala hidup dalam komunitas masyarakat adalah terkadang timbul suatu ketegangan sebagai suatu akibat dari perbedaan antara pola-pola perikelakuan masyarakat. Bahkan seringkali terjadi benturan-benturan kepentingan yang melahirkan perselisihan atau sengketa di antara anggota masyarakat. ${ }^{2}$

Untuk menghindarkan atau meminimalisir gejala tersebut, diperlukan suatu ketentuan yang harus ditaati oleh setiap anggota masyarakat. Oleh sebab itu, diperlukan suatu badan peradilan yang berfungsi melaksanakan kekuasaan kehakiman untuk menegakkan hukum dan keadilan. Hal ini sesuai dengan firman Allah swt:

"Dan hendaklah kamu memutuskan perkara di antara mereka menurut apa yang diturunkan Allah, dan janganlah kamu mengikuti hawa nafsu mereka. Dan berhati-hatilah kamu terhadap mereka, supaya mereka tidak memalingkan kamu dari sebahagian apa yang telah diturunkan Allah kepadamu.Jjika mereka berpaling (dari hukum yang telah diturunkan Allah), maka ketahuilah bahwa sesungguhnya Allah menghendaki akan menimpakan mushibah kepada mereka disebabkan sebahagian dosa-dosa mereka. Dan sesungguhnya kebanyakan manusia adalah orang-orang yang fasik".(Q.S: Al-Maidah: 49). ${ }^{3}$

Bahwa melalui ayat ini Allah mengulangi perintahnya untuk menetapkan hukum sesuai dengan apa yang diturunkannya. Dan perintah pada ayat ini adalah karena apa yang diturunkan Allah itu merupakan kemaslahatan manusia. Firman ini menekankan kewajiban berpegang teguh terhadap apa yang diturunkan Allah secara utuh dan tidak mengabaikannya walaupun sedikitpun. ${ }^{4}$

Pembahasan tentang masalah pembuktian dalam pengadilan, memiliki keterkaitan dengan sebuah peribahasa "Errare Humanumm Est",

\footnotetext{
1 Hidajatul Hidajah, Peta Pemikiran Sosiologi dan Perkembangannya, (Surabaya: Putra Pelajar, 2003), 2.

${ }^{2}$ Soejono Soekamto, Pokok-Pokok Sosiologi Hukum, (Jakarta: Raja Grafindo Persada, 1999), 19.

${ }^{3}$ Departemen Agama, Al-Qur'an dan Terjemahnya, (Surabaya: Al-Hidayah, 2002),154.

${ }^{4}$ M. Quraish Shihab, Tafsir Al-Misbah V. 3, (Jakarta: Lentera Hati, 2001), 116.
} 
"Khilaf adalah insanah" manusia tidak luput dari kekhilafan dan kekeliruan. ${ }^{5}$

Seorang hakim yang juga seorang manusia, mungkin tidak selalu menyadari bahwa dia telah melakukan kesalahan. Demikian pula kekeliruan dan keluputan ingatan para saksi, prasangka, dan anggapannya dapat mengakibatkan hukuman dan penderitaan terhadap seorang terdakwa, bahkan kekhilafan itu bisa menggiring seorang terdakwa ke tiang gantungan atau ke muka regu tembak. Sebab sering kali dijumpai dan baru disadari suatu kekeliruan putusan pengadilan datang pada saat yang terlambat ketika seorang tersangka telah terlanjur dihukum mati tanpa salah, padahal hidup manusia hanya sekali dan tidak terulang (Ein Malig). ${ }^{6}$ Hakim dituntut untuk menegakkan keadilan. Oleh karena itu, hakim tidak boleh bertindak sewenang-wenang dan hanya berdasar atas keyakinan nalurinya dalam mengambil keputusan final dan memberikan vonis pidana kepada seorang terdakwa tanpa mempertimbangkan dan melihat alat-alat bukti yang ada.

Keharusan adanya pembuktian terkadang menjadi dilema bagi masyarakat, karena sering kali sesuatu yang sebenarnya benar harus ditolak hanya karena si terdakwa tidak dapat membuktikan tentang kebenaran dirinya. Sementara itu, sebaliknya harus dibenarkan kesaksian yang tidak dapat dibuktikan walaupun sebenarnya adalah suatu bukti yang mengandung kesamaran dan dipalsukan.

Pembuktian di muka pengadilan adalah merupakan hal yang terpenting dalam hukum acara, sebab pengadilan dalam menegakkan hukum dan keadilan tidak lain berdasarkan atas pembuktian. Karena dengan pembuktian yang cermat dan tepat akan memberikan gambaran yang jelas kepada hakim tentang peristiwa yang terjadi, sehingga hakim dapat mengkualifikasi permasalahannya yang kemudian dapat mengkonstituir untuk menjatuhkan putusan yang seadil-adilnya. ${ }^{8}$

Dalam menyelesaikan suatu perselisihan atau perkara, hakim memerlukan suatu pembuktian untuk memutuskan siapa yang salah dan siapa yang benar. Tanpa adanya pembuktian yang sah hakim tidak dapat begitu saja memutuskan perkara yang ada, apalagi dalam hal hakim

\footnotetext{
${ }^{5}$ Herman Mostar, Peradilan yang Sesat, (Jakarta: Pustaka Utama Grafiti, 1987), 1.

${ }^{6} \mathrm{lbid} ., 2$.

${ }^{7}$ Anshoruddin, Hukum Pembuktian menurut Hukum Acara Islam dan Hukum Positif, (Yogyakarta: Pustaka Pelajar, 2004), 35.

${ }^{8}$ Roihan A. Rasyid, Hukum Acara Peradilan Agama, (Jakarta: Raja Grafindo Persada, 1994), 137.
} 
memutus perkara pidana yang bertujuan untuk mengejar kebenaran materiil, yaitu kebenaran yang didasarkan kepada alat-alat bukti yang sah dan hakim mempunyai keyakinan bahwa suatu tindak pidana benar-benar terjadi dan terdakwa yang bersalah melakukan hal ini selaras dengan pasal 183 KUHAP yang berbunyi:

Hakim tidak boleh menjatuhkan pidana kepada seseorang kecuali apabila dengan sekurang-kurangnya dua alat bukti yang sah ia memperoleh keyakinan bahwa suatu tindak pidana benar-benar terjadi dan bahwa terdakwalah yang bersalah melakukannya. ${ }^{9}$

Dalam perkara pidana, pada tahap pengadilan kadang pengakuan dan keterangan terdakwa sering kali dipalsukan dan dibuat salah oleh seorang terdakwa. Keterangan dan pengakuan tersebut bisa saja terjadi dikarenakan pada tahap pemeriksaan seorang terdakwa mengalami beban yang berat, hal inilah yang kadang membuat hakim keliru dalam mengambil keputusan final. Sehingga pengadilan dalam konteks ini bisa dianggap sebagai media untuk membenarkan orang-orang yang seharusnya salah dan menyalahkan orang-orang yang seharusnya benar. Permasalahan inilah yang perlu dikaji ulang dalam rangka untuk mencari kebenaran dan keadilan yang sesugguhnya.

Dalam praktik, hakim memang tugas utamanya menerima, memeriksa, mengadili dan memutus perkara, namun demikian dalam konteks dan sistem penegakan hukum di pengadilan-pengadilan, hakim belum mampu menyelesaikan sengketa dan menegakkan keadilan. Dalam sistem kondisi dan keadaan sistem peradilan yang dibangun dengan model dan paradigma hukum yang legalistik dan formalistik (Eropa kontinental) mengarahkan hakim bukan sebagai corong keadilan (speaker of justice) tetapi hakim hanya sekedar sebagai corong Undang-Undang (speaker of law). ${ }^{10}$

Keharusan pembuktian ini dalam hukum Islam didasarkan atas firman Allah swt. QS. Al-Baqarah 2:282,

“...dan persaksikanlah dengan dua orang saksi dari orang-orang lelaki diantaramu, jika tidak ada dua orang saksi, maka (boleh) seorang lelaki dan dua orang perempuan dari saksi-saksi yang kamu ridloi, supaya jika

\footnotetext{
${ }^{9}$ Andi Hamzah dan Irdan Dahlan, KUHAP, HIR dan Komentar, (Jakarta: Cholia Indonesia, 1985), 235.

${ }^{10}$ Sidik Sunaryo, Kapita Selekta Sistem Peradilan Pidana, (Malang: UMM Press, 2004), 27.
} 
seseorang lupa maka seorang lagi mengingatkannya. Janganlah saksi-saksi itu enggan (memberi keterangan) apabila mereka dipanggil..". ${ }^{11}$

Dalam hukum Islam, banyak sekali alat bukti ${ }^{12}$ yang digunakan untuk menyelesasikan suatu perkara. Sedangkan alat bukti yang sah menurut fuqaha ada 7 macam, yaitu:

1. Iqrâr (Pengakuan))

2. Syahâdah (kesaksian)

3. Yamîn (Sumpah)

4. Nukûl (Penolakan sumpah)

5. Qasâmah (bersumpah 50 orang)

6. Pengetahuan Hakim)

7. Qarînah (petunjuk))

Dalam Hukum Acara Pidana, perihal alat-alat bukti tercantum dalam pasal 184 KUHAP, yang dinyatakan dalam pasal itu bahwa alat-alat bukti yang sah terdiri dari:

1. Keterangan saksi dinyatakan oleh pasal 1 butir 27 KUHAP yang dimaksud keterangan saksi adalah salah satu alat bukti dalam perkara pidana yang berupa keterangan dari saksi mengenai suatu peristiwa pidana yang ia dengar sendiri, ia lihat sendiri dan ia alami sendiri dengan menyebut alasan dari pengetahuannya. ${ }^{13}$

2. Keterangan ahli adalah keterangan yang diberikan oleh seorang yang memiliki keahlian khusus tentang hal yang diperlukan untuk membuat terang suatu perkara pidana guna kepentingan pemeriksaan. ${ }^{14}$

3. Menurut ketentuan pasal 187 surat yang dapat dinilai sebagai alat bukti yang sah menurut undang-undang adalah surat yang dibuat atas sumpah jabatan atau surat yang dikuatkan dengan sumpah. ${ }^{15}$

4. Petunjuk adalah perbuatan, kejadian atau keadaan yang karena persesuaiannya baik antara yang satu dengan yang lain, maupun dengan tindak pidana itu sendiri, menandakan bahwa telah terjadi suatu tindak pidana dan siapa pelakunya. ${ }^{16}$

\footnotetext{
${ }^{11}$ Departemen Agama RI. Al-Qur'an dan Terjemahnya, 59.

${ }^{12}$ Alat bukti artinya adalah alat atau upaya yang bisa dipergunakan oleh pihak-pihak yang berperkara untuk meyakinkan hakim di muka pengadilan. Roihan Rasyid, Hukum Acara Peradilan Agama, 148-149.

${ }^{13}$ Andi Hamzah, KUHP dan KUHAP, (Jakarta: Rineka Cipta, 1992), 233.

${ }^{14} \mathrm{lbid}$.

${ }^{15}$ Yahya Harahap, Pembahasan Permasalahan dan Penerapan KUHAP, (Jakarta: Sinar Grafika, 2000), 285.

${ }^{16}$ Andi Hamzah, KUHP dan KUHAP, 308.
} 
5. Keterangan terdakwa adalah apa yang terdakwa nyatakan di sidang tentang perbuatan yang ia lakukan atau yang ia ketahui sendiri atau alami sendiri. ${ }^{17}$

Dalam artikel ini penekanan bahasan hanya pada persumpsion. Menurut Anshoruddin, dalam Hukum Acara Islam persumpsion disebut dengan qarînah (petunjuk) yang berarti "Tanda yang merupakan hasil kesimpulan Hakim dalam menangani berbagai kasus melalui ijtihad". Sedangkan dalam hukum positif, persumpsion adalah perbuatan, kejadian atau keadaan yang karena persesuaiannya baik antara yang satu dengan yang lain, maupun dengan tindak pidana itu sendiri, menandakan bahwa telah terjadi suatu tindak pidana dan siapa pelakunya.

Terkait dengan istilah persumpsion yang menjadi masalah dasar dalam menentukan obyek kajian penelitian ini adalah bahwa alat bukti dan proses pembuktian tindak pidana pengadilan itu berada dalam wilayah yuridis formal sehingga sah tidaknya sesuatu untuk digunakan sebagai alat bukti amat bergantung pada ketentuan-ketentuan formal yang mengaturnya.

Berangkat dari latar belakang masalah diatas diperlukan pembahasan yang lebih mendalam yang menjelaskan apakah persumpsion itu dapat diterima sebagai alat bukti. Tentunya dalam hal ini perlu dilihat dari berbagai perspektif agar obyektifitasnya dapat lebih terjamin.

Oleh karena itu dalam artikel ini, penulis akan menguraikan tentang keabsahan atau kekuatan persumpsion dalam dua tinjauan keilmuan yaitu dalam perspektif Hukum Acara Islam dan Hukum Acara Pidana. Dalam Hukum Acara Islam penulis akan menyoroti pokok bahasan ini dengan menggunakan sudut pandang beberapa ulama dalam bidang fikih, yang selanjutnya penulis akan lebih spesifik menyoroti persoalan ini melalui aturan-aturan yang tertuang dalam Hukum Acara Pidana.

\section{Pengertian Pembuktian}

Dalam syariat Islam, penjelasan mengenai prinsip-prinsip tentang pembuktian tidaklah banyak berbeda dengan yang terdapat pada perundang-undangan yang berlaku di zaman modern sekarang ini. Sebab pada dasarnya, prinsip dalam perundang-undangan dalam Islam dan perundang-undangan yang terdapat di zaman modern merupakan satu kesatuan besar yang saling berkaitan.

\footnotetext{
${ }^{17}$ Ibid., 309.
} 
Sebelum melangkah pada pembahasan mengenai teori dan sistem pembuktian dan dasar hukum pembuktian serta kewajiban pembuktian sebelumnya penulis akan memberikan deartikel tentang pengertian pembuktian.

Pembuktian secara etimologi berasal dari kata "bukti" yang berarti sesuatu yang menyatakan suatu peristiwa, kata "bukti" jika mendapatkan awalan "pe" dan akhiran "an" maka berarti "proses", "perbuatan", "caracara membuktikan" sedangkan secara terminologi pembuktian berarti usaha membuktikan benar atau salahnya si terdakwa dalam sidang pengadilan, ${ }^{18}$ sehingga yang dimaksud "membuktikan" ialah meyakinkan seorang hakim tentang kebenaran akan dalil-dalil yang dikemukakan dalam suatu persengketaan. ${ }^{19}$

Menurut Subekti, pembuktian ialah suatu proses bagaimana alatalat bukti tersebut dipergunakan, diajukan atau dipertahankan untuk meyakinkan Hakim tentang kebenaran dalil-dalil yang dikemukakan dalam suatu perkara. ${ }^{20}$

Sedangkan Subhi Mahmasani memberikan gambaran mengenai pengertian pembuktian yakni membuktikan suatu perkara adalah "mengajukan alasan dan memberikan dalil sampai pada batas yang meyakinkan". Yang dimaksud meyakinkan ialah apa yang menjadi ketetapan atau keputusan atas dasar penelitian dan dalil-dalil itu, karena itu hakim harus mengetahui apa yang menjadi gugatan dan mengetahui hukum Allah terhadap gugatan tersebut, sehingga kepada hakim yang memeriksa suatu perkara tersebut memperoleh kesimpulan guna menetapkan apakah seseorang itu memiliki hak atau tidak.

Membuktikan itu hanyalah terjadi dalam hal adanya perselisihan mengenai suatu hak antara dua pihak atau lebih, yang masing-masing pihak merasa memiliki atas hak tersebut. ${ }^{21}$ Sehingga membuktikan dapat diartikan mempertimbangkan secara logis kebenaran suatu fakta atau peristiwa berdasarkan alat-alat bukti yang sah menurut hukum pembuktian yang berlaku. ${ }^{22}$

\footnotetext{
${ }^{18}$ Departemen Pendidikan dan Kebudayaan, Kamus Bahasa Indonesia, (Jakarta: Balai Pustaka, 1995), 151.

${ }^{19}$ R. Subekti, Hukum Pembuktian, (Jakarta: Pradnya Paramita, 1975), 1.

${ }^{20}$ Ibid., 7.

${ }^{21}$ Anshoruddin, Hukum Pembuktian menurut Hukum Acara Islam dan Hukum Positif, 35.

${ }^{22}$ Mukti Arto, Praktek Perkara Perdata, (Jogjakarta: Pustaka Pelajar, 2003), 139.
} 
Dalam pendapat lain, menurut Sudikno Mertokusumo bahwa "membuktikan" mempunyai beberapa pengertian yaitu arti logis, konvensional, dan yuridis dengan penjelasan sebagai berikut:

1. Membuktikan dalam arti logis ialah memberikan kepastian yang bersifat mutlak, berlaku bagi setiap orang dan tidak memungkinkan adanya bukti lawan. Contohnya adalah berdasarkan axioma bahwa dua garis yang sejajar tidak mungkin bersilang.

2. Pembuktian dalam arti konvensional adalah memberikan kepastian yang bersifat nisbi atau relatif.

3. Membuktikan dalam arti yuridis ialah memberikan dasar-dasar yang cukup kepada hakim yang memeriksa perkara yang bersangkutan guna memberi kepastian tentang kebenaran peristiwa yang diajukan. ${ }^{23}$

Pada dasarnya, dalam satu proses pembuktian perkara yang dicari adalah kebenaran formal, yakni kebenaran yang berdasarkan atas anggapan dari pihak yang berperkara. Hal ini disebabkan karena yang dicari dalam hukum acara pidana adalah kebenaran material, yaitu kebenaran sejati yang harus diusahakan demi tercapainya satu tujuan, sehingga tujuan pembuktian adalah untuk memperoleh kepastian bahwa suatu peristiwa atau fakta yang diajukan adalah benar-benar terjadi guna mendapatkan putusan hukum yang benar dan adil. ${ }^{24}$

Dengan kata lain, pembuktian adalah suatu proses bagaimana alatalat bukti tersebut dipergunakan, diajukan maupun dipertahankan sesuai hukum acara yang berlaku dan bahwa hakim tidak boleh menjatuhkan pidana kepada seseorang kecuali apabila sekurang-kurangnya terdapat dua alat bukti yang sah. Dia memperoleh keyakinan bahwa suatu tindak pidana benar-benar terjadi dan bahwa seorang terdakwalah yang benarbenar bersalah melakukan tindak pidana dan dapat dijatuhi hukuman. ${ }^{25}$

\section{Teori dan Sistem Pembuktian Dalam Hukum Acara Pidana Islam}

Sebelum memasuki pembahasan tentang kekuatan yuridis persumpsion dalam proses pembuktian perkara, maka kiranya dibahas terlebih dahulu tentang jenis-jenis teori dan sistem pembuktian yang berlaku atau digunakan dalam hukum acara pidana Islam.

Satu hal mendasar yang perlu diketahui bahwa hukum pembuktian yang berlaku pada masyarakat tradisional Indonesia zaman dahulu sering

\footnotetext{
${ }^{23}$ Sudikno Mertokusumo, Hukum Acara perdata Indonesia, (Jogjakarta: Liberti, 1996), 108.

${ }^{24}$ Mukti Arto, Praktek Perkara Perdata, 139.

${ }^{25}$ Roihan Rasyid, Hukum Acara Peradilan Agama, 151.
} 
digantungkan pada kekuatan Tuhan, seperti halnya zaman dahulu dikenal tentang cara pembuktian dengan membuat asap pada guci abu Raja yang dianggap paling adil dan bijaksana, kemana asap itu mengarah pihak itulah yang dianggap paling benar. Sedangkan model peradilan pidana di Indonesia yang masih dipakai saat ini adalah model yuridis yang mana ciri model ini adalah sabagai berikut: strukturnya relatif tetap dan tertutup terhadap bidang-bidang lain. ${ }^{26}$ Dan dalam prakteknya model ini masih lazim dipakai dalam setiap pengadilan, dengan menerapkan aturan hukum yang berlaku terhadap kejadian obyektif dan kemudian seorang hakim akan melakukan tugasnya dengan menggunakan cara berfikir dalam pengambilan keputusan dengan memperhatikan bagian-bagian seperti:

a. Mayor: kejadian obyektif (kenyataan)

b. Minor: aturan hukum

c. Konklusi: keputusan yaitu keputusan yang telah ditetapkan dan ditunjuk oleh aturan-aturan hukum. ${ }^{27}$

Sedangkan mengenai teori-teori pembuktian yang sifatnya kontemporer dalam hukum acara pidana Islam tidak dijelaskan secara baku akan tetapi dalam hukum acara pidana Islam dalam konteks hukum acara perdata tentang bahasan mengenai proses pembuktian sering menggunakan teori-teori yang juga dipakai oleh hukum acara pidana positif sehingga proses pembuktian yang terdapat dalam hukum acara pidana Islam dan hukum acara pidana positif adalah merupakan suatu kesatuan yang tidak dapat dipisahkan.

Bertitik tolak dari bahasan di atas, maka dianggap perlu untuk diketahui bahwa umumnya pada masyarakat primitif pertumbuhan hukum yang kemudian dipisahkan dalam hukum privat dan hukum publik dalam dunia modern tidaklah membedakan kedua bidang hukum tersebut sebagaimana hukum acara yang digunakan dalam hukum perdata tidaklah terpisah dari hukum pidana baik di Indonesia maupun di dunia barat (termasuk Belanda). Tuntutan perdata dan tuntutan pidana merupakan suatu kesatuan termasuk lembaga-lembaganya. ${ }^{28}$ Misalnya lembaga jaksa atau penuntut umum adalah lembaga baru tidak terdapat pada masyarakat primitif. Negara Perancis yang biasa disebut sebagai tempat kelahiran lembaga itu menyatakan bahwa sebenarnya istilah jaksa

\footnotetext{
${ }^{26}$ Roeslan Saleh, Hukum Pidana sebagai Konfrontasi Manusia dan Manusia, Jakarta: Sinar Grafika, 1998), 9.

${ }^{27} \mathrm{lbid}$.

${ }^{28}$ Andi Hamzah, Hukum Acara Pidana Indonesia, 4.
} 
sendiri berasal dari bahasa sansekerta "Adhyaksa" yang berarti sama dengan hakim pada dunia modern sekarang ini. Di Belanda pun pada zaman dahulu dikenal istilah Officer Van Justitie. Mula-mula dikenal istilah schout yang khusus menuntut pidana. ${ }^{29}$ Dari sinilah sehingga aturan-aturan khususnya teori-teori yang digunakan dalam proses pembuktian dan penyelesaian perkara pidana baik dalam hukum acara pidana positif maupun hukum acara pidana Islam dan juga hukum perdata merupakan suatu kesatuan dan aturan besar yang saling berhubungan.

Sehubungan dengan proses penilaian pembuktian pengadilan dalam konteks hukum acara Islam dimana hakim tidak dapat bertindak bebas atau diikat oleh undang-undang maka timbullah pertanyaan, sejauh manakah hukum acara pidana Islam boleh mengikat hakim dalam proses pembuktian perkara pidana dalam persidangan. Tentang hal ini terdapat tiga teori antara lain:

a. Teori pembuktian bebas

Teori ini tidak menghendaki adanya ketentuan-ketentuan yang mengikat hakim, sehingga penilaian pembuktian seberapa dapat diserahkan kepadanya. ${ }^{30}$ Dalam teori ini hakim dalam menjalankan tugasnya harus sebagai seorang ahli dalam bidangnya dan selalu mengikuti perkembangan ilmu pengetahuan, dan keputusannya harus up to date, tidak hanya terpaku hanya kepada suatu perundang-undangan yang berlaku, ia wajib mengikuti perkembangan dan kemajuan masyarakat.

Dalam memutus perkara, hakim tidak terikat kepada undangundang semata akan tetapi harus didasarkan pada ilmu pengetahuan dan logika sehingga keputusan yang diberikan dapat menyentuh rasa keadilan masyarakat pada zamannya. ${ }^{31}$ Adapun syarat seorang hakim dalam menggunakan sistem pembuktian ini ada beberapa syarat:

1) Harus berdasarkan alat bukti yang sah.

2) Menurut keyakinan hakim. ${ }^{32}$

b. Teori pembuktian negatif

Menurut teori ini harus ada ketentuan yang mengikat yang bersifat negatif, bahwa ketentuan ini harus membatasi pada larangan seorang

\footnotetext{
${ }^{29}$ Ibid., 45.

${ }^{30}$ Bambang Waluyo, Sistem Pembuktian dalam Peradilan di Indonesia, (Jakarta: Sinar Grafika, 1996), 7.

${ }^{31}$ Suharto RM, Penuntutan Dalam Praktek Peradilan, (Jakarta: Sinar Grafika, 1997), 134.

${ }^{32}$ Andi Thahir Hamid, Hukum Acara Pidana Umum dan Hukum Acara Pidana Khusus, (Surabaya: CV. Al-lkhsan, 1993), 130.
} 
hakim untuk melakukan sesuatu yang berhubungan dengan pembuktian. ${ }^{33}$

Dalam teori ini apabila tindak pidana sudah dibuktikan dan ternyata terdakwa terbukti melanggar hukum dan dinyatakan bersalah maka hakim dalam memutus perkara pidana masih memerlukan keyakinan atas tindak pidana yang sudah terbukti dan yang dinyatakan salah itu.

Bahwa hakim sebelum menjalankan tugasnya telah mengangkat sumpah terlebih dahulu, diharapkan tidak akan terpengaruhi dari luar keyakinannya sedangkan dalam batinnya para hakim wajib menggali, mengikuti dan memahami nilai-nilai hukum yang hidup dalam masyarakat. ${ }^{34}$

c. Teori pembuktian positif

Teori ini didasarkan pada kemurnian undang-undang atau aturanaturan, artinya seorang hakim dalam memutuskan suatu perkara bisa berdasarkan undang-undang yang berarti tugas hakim hanya sebagai pelaksana biasa. ${ }^{35}$

Dalam praktek, hakim memang tugas utamanya menerima, memeriksa, mengadili dan memutus perkara, namun demikian dalam konteks dan sistem penegakan hukum di pengadilan-pengadilan, hakim belum mampu menyelesaikan sengketa dan menegakkan keadilan. Dalam sistem kondisi dan keadaan sistem peradilan yang dibangun dengan model dan paradigma hukum yang legalistik dan formalistik (eropa kontinental) mengarahkan hakim bukan sebagai corong keadilan (speaker of justice) tetapi hakim hanya sekedar sebagai corong Undang-Undang (speaker of law). ${ }^{36}$

Dalam ajaran teori pembuktian ini memberi kesempatan bagi orang melakukan perbuatan yang pada hakikatnya dia melakukan kejahatan tapi karena tidak diatur dalam undang-undang sebagai tindak pidana, maka dia lepas dari tuntutan pidana disamping adanya larangan teori ini menghendaki adanya perintah kepada hakim.

Sedangkan terkait dengan teori-teori dan sistem pembuktian dalam hukum acara pidana Islam dan mengingat asas atau prinsip-prinsip dalam

\footnotetext{
${ }^{33}$ Bambang Waluyo, Sistem Pembuktian dalam Peradilan di Indonesia, 7.

${ }^{34} \mathrm{Ibid}$.

${ }^{35}$ Suharto RM, Penuntutan dalam Praktek Peradilan, 132.

${ }^{36}$ Sidik Sunaryo, Kapita Selekta Sistem Peradilan Pidana, 28.
} 
pembuktian agar hakim dapat menyelesaikan perkara yang diajukan dan keputusannya memenuhi tuntutan pengadilan maka hakim wajib:

a. Mengetahui hakikat dakwaan atau gugatan

b. Mengetahui hukum-hukum Allah yang terdapat dalam perkara tersebut. ${ }^{37}$

\section{Dasar Hukum dan Kewajiban Pembuktian dalam Hukum Acara Pidana Islam}

Pada dasarnya, suatu perkara pidana yang sampai di depan persidangan pengadilan bermula dari adanya suatu perbuatan atau pelanggaran hak yang dilakukan oleh seseorang, karena antara pihak yang melanggar dan pihak yang dirugikan haknya tidak dapat menyelesaikan perkara dengan sebaik-baiknya melalui jalan perdamaian secara pribadi, maka sesuai dengan prinsip negara hukum, maka cara penyelesaiannya hanya dapat dilakukan melalui saluran hukum yaitu melalui institusi yang bernama pengadilan. ${ }^{38}$ Mengenai dasar hukum mengenai kewajiban dan adanya perintah pembuktian terdapat pada QS. Al-Baqarah (282) yang berbunyi:

“...dan persaksikanlah dengan dua orang saksi dari orang-orang lelaki di antaramu, jika tidak ada dua orang saksi, maka (boleh) seorang lelaki dan dua orang perempuan dari saksi-saksi yang kamu ridloi, supaya jika seseorang lupa maka seorang lagi mengingatkannya. Janganlah saksi-saksi itu enggan (memberi keterangan) apabila mereka dipanggil.." ${ }^{39}$

Maka dari ayat tersebut dapat dipahami bahwa barang siapa yang mengajukan perkara untuk menuntut haknya maka orang itu harus mampu membuktikan dengan menyertakan alat-alat bukti yang mampu mendukungnya.

Dalam hukum acara peradilan Islam, untuk membuktikan kebenaran gugatannya adalah tugas dari penggugat, sebab menurut asal segala urusan itu diambil dari yang lahirnya maka wajib atas orang yang mengemukakan gugatannya atas suatu yang lahir untuk membuktikan kebenaran gugatannya. Hal tersebut sebagaimana kaidah kulliyyah yang menyatakan sebagai berikut:

"Bukti adalah untuk menetapkan yang berbeda dengan keadaan dhahir dan sumpah untuk menetapkan keadaan-keadaan asalnya." ${ }^{40}$

\footnotetext{
${ }^{37}$ M. Salam Madkur, Peradilan dalam Islam, (Surabaya: Bina Ilmu, 1993), 92.

${ }^{38}$ Anshoruddin, Hukum Pembuktian menurut Hukum Acara Islam dan Hukum Positif, 32.

${ }^{39}$ Departemen Agama RI. Al-Qur'an dan Terjemahnya, 59.

${ }^{40}$ Anshoruddin, Hukum Pembuktian menurut Hukum Acara Islam dan Hukum Positif, 42.
} 
Kaidah ini didasarkan pada hadits Nabi yang berbunyi

"Bukti itu atas si penggugat dan sumpah itu atas si tergugat." 41

Hadis tersebut di atas digunakan sebagai dasar hukum pembebanan pembuktian artinya penggugat harus dapat membuktikan bahwa isi gugatannya itu benar, dan sebaliknya bagi pihak yang tergugat sebelumnya menyampaikan jawaban atas gugatannya akan dikenakan sumpah. ${ }^{42}$ Ketentuan ini digunakan untuk menjamin tegaknya keadilan, kebenaran, dan kepastian hukum bagi seseorang.

Sebagai usaha untuk mengetahui benar atau tidaknya seseorang yang sedang berperkara dalam pengadilan dengan mengedepankan segala aspek terutama perihal alat-alat bukti. Maka dalam hal ini perlu adanya pembahasan mengenai alat-alat bukti dalam hukum acara pidana Islam.

Beberapa pendapat mengenai alat bukti antara lain:

Menurut Samir 'Aliyah, alat-alat bukti ada 8 dengan urutan sebagai berikut: ${ }^{43}$

1. Pengakuan

2. Saksi

3. Sumpah

4. Penolakan sumpah

5. Qarînah

6. Qasâmah

7. Qiyafah

8. Qur'ah .

Menurut Sayyid Sabiq, alat-alat bukti itu ada 4 dengan urutan sebagai berikut: ${ }^{44}$

1. Pengakuan

2. Saksi

3. Sumpah

4. Surat Resmi

Sedangkan di bawah ini disebutkan alat-alat bukti yang sah yang dipakai dalam hukum acara pidana Islam:

1. Pengakuan

Pengakuan dalam arti bahasa dapat dikatakan sebagai penetapan, sedangkan pengakuan dalam syara' adalah suatu pernyataan yang

\footnotetext{
${ }^{41}$ Bukhori, Shahih Bukhari, (Beirut: Dar al-Fikr, ), 116.

${ }^{42}$ Anshoruddin, Hukum Pembuktian menurut Hukum Acara Islam dan Hukum Positif, 43.

${ }^{43}$ Ibid., 57.

${ }^{44}$ Sayyid Sabiq, Fiqih Sunnah Jilid 3, cet. 4 (Beirut: Dar al-Fikr, tt.), 328.
} 
menceritakan kebenaran atau mengakui kebenaran tersebut. Berikut dasar hukum mengenai pengakuan yang terdapat dalam firman Allah QS. anNisa' 135:

"Wahai orang-orang yang beriman, jadilah kamu orang yang benar-benar penegak keadilan, menjadi saksi karena Allah biarpun terhadap dirimu sendiri atau ibu bapa dan kaum kerabatmu. jika ia Kaya ataupun miskin, Maka Allah lebih tahu kemaslahatannya. Maka janganlah kamu mengikuti hawa nafsu karena ingin menyimpang dari kebenaran. dan jika kamu memutar balikkan (kata-kata) atau enggan menjadi saksi, Maka Sesungguhnya Allah adalah Maha mengetahui segala apa yang kamu kerjakan". 45

Dalam hal pengakuan, para fukaha memberikan istilah yakni "mengabarkan suatu hak orang lain". ${ }^{46}$ Sedangkan menurut Salam Madkur adalah "mengakui adanya hak orang lain yang ada pada diri pengaku itu sendiri dengan ucapan atau yang berstatus sebagai ucapan" ${ }^{47}$

Sedangkan ketentuan yang terdapat dalam alat bukti pengakuan:

a. Orang yang berakal sehat tidak akan melakukan kebohongan yang akibatnya akan merugikan dirinya, karena itu pengakuan lebih kuat daripada persaksian dan dapat digunakan sebagai alat bukti untuk semua jenis tindak pidana.

b. Pengakuan yang dapat diterima sebagai alat bukti adalah pengakuan yang jelas, terperinci dan pasti sehingga tidak bisa ditafsirkan lain kecuali dalam perbuatan pidana yang dilakukannya.

c. Pengakuan harus benar dan tidak dipaksa (terpaksa) pengakuan harus timbul dari orang yang berakal dan mempunyai kebebasan (pilihan).

2. Persaksian

Persaksian menurut syara' adalah pemberitaan yang pasti yaitu ucapan yang keluar yang diperoleh dari orang lain karena beritanya telah tersebar. ${ }^{48}$ Persaksian merupakan pemberitahuan (pernyataan) yang benar untuk membuktikan suatu kebenaran dengan sumpah di depan pengadilan.

Sedangkan dasar hukum mengenai persaksian itu sesuai dengan firman Allah dalam QS. al-Maidah (5) 106 yang berbunyi:

\footnotetext{
${ }^{45}$ Departemen Agama RI. Al-Qur'an dan Terjemahnya, 131.

${ }^{46}$ Anshoruddin, Hukum Pembuktian menurut Hukum Acara Islam dan Hukum Positif, 93.

${ }^{47}$ Salam Madkur, Peradilan dalam Islam, (Surabaya: Bina Ilmu, 1993), 100.

${ }^{48}$ Anshoruddin, Hukum Pembuktian menurut Hukum Acara Islam dan Hukum Positif, 73.
} 
"Hai orang-orang yang beriman, apabila salah seorang kamu menghadapi kematian, sedang Dia akan berwasiat, maka hendaklah (wasiat itu) disaksikan oleh dua orang yang adil di antara kamu, atau dua orang yang berlainan agama dengan kamu, jika kamu dalam perjalanan di muka bumi lalu kamu ditimpa bahaya kematian...". 49

Dan QS. an-Nur ayat 4 yang berbunyi:

"Dan orang-orang yang menuduh wanita-wanita yang baik-baik (berbuat zina) dan mereka tidak mendatangkan empat orang saksi, maka deralah mereka (yang menuduh itu) delapan puluh kali dera, dan janganlah kamu terima kesaksian mereka buat selama-lamanya. dan mereka itulah orangorang yang fasik". ${ }^{0}$

Ketentuan-ketentuan yang terdapat alat bukti persaksian:

a. Tindak pidana yang hukumannya mâliyyah dapat dibuktikan dengan seorang saksi tanpa diperkuat dengan sumpah, apabila Hakim mempercayai dan meyakini keterangan yang disampaikan saksi tersebut. Dan apabila hakim tidak meyakini keterangan saksi karena keterangannya meragukan maka hakim dapat menolaknya.

b. Pada dasarnya kunci untuk diterimanya kesaksian adalah adanya keyakinan hakim.

3. Qasâmah

Ialah sumpah yang disumpahkan kepada wali orang yang terbunuh apabila mereka mengetahui darah atau dituntut darahnya. Menurut imam al-Haramain, al-qasâmah menurut ahli bahasa adalah nama lain bagi orang-orang yang bersumpah, sedangkan menurut kamus adalah sekelompok orang yang bersumpah atas sesuatu dan mengambilnya atau menyelesaikannya. ${ }^{51}$

Berikut ketentuan-ketentuan dalam hukum acara pidana Islam:

1) Qasâmah merupakan cara pembuktian yang dilakukan untuk tindak pidana pembunuhan, (apabila pelakunya diketahui tetapi tidak ada bukti yang kuat yang menyatakan bahwa dia yang membunuh korban).

2) Qasâmah dilakukan oleh wali (keluarga si terbunuh) untuk membuktikan pembunuhan oleh tersangka atau dilakukan oleh tersangka untuk membuktikan bahwa dia tidak melakukan pembunuhan.

4. Qarînah

\footnotetext{
${ }^{49}$ Departemen Agama RI, Al-Qur'an dan Terjemahnya, 166.

${ }^{50}$ Ibid., 488.

51 Salam Madkur, Peradilan dalam Islam, 13.
} 
Secara bahasa artinya istri atau hubungan atau pertalian. Sedangkan menurut istilah hukum ialah hal-hal yang mempunyai hubungan atau pertalian yang erat sedemikian rupa terhadap sesuatu sehingga memberi petunjuk. ${ }^{52}$ Dapat juga diambil dari kata muqâranah yang berarti mushâhabah (petunjuk). ${ }^{53}$ Sedangkan secara istilah qarînah dapat diartikan dengan:

"Tanda-tanda yang merupakan hasil kesimpulan hakim dalam menangani berbagai kasus melalui ijtihad".

Tanda-tanda tersebut dapat menimbulkan keyakinan. Qarînah itu terbagi dua yaitu:

1) Qarînah qânûniyyah yaitu qarînah yang ditentukan undang-undang seperti contoh bahwa Amr bin Mas'ud menjatuhkan hukum had kepada seorang yang dari mulutnya keluar bau bekas minum khamar. ${ }^{54}$

2) Qarînah qadhâiyyah yaitu qarînah yang merupakan kesimpulan hakim setelah memeriksa perkara seperti contoh kalau ada dan dapat dibuktikan seorang lelaki muda dan seorang perempuan muda dituduh berzina, sedangkan keduanya terbukti telah menginap dalam satu kamar di hotel dengan satu tempat tidur maka dengan persangkaan hakim dianggaplah terbukti keduanya telah melakukan zina.

Ulama-ulama Hanafiyah banyak mempergunakan bukti qarînah ini. Dan bukti-bukti ini didasarkan kepada pertimbangan hakim, kenyataan yang terjadi, serta 'urf masyarakat. Sedangkan Teungku Hasbi as-Shiddiqieqi dalam bukunya menyatakan bahwa qarînah-qarînah ini terbagi menjadi dua:

Qarînah 'urfiyah. Qarînah ini ditakrifkan sebagai "Kesimpulankesimpulan yang ditanggapi hakim dari sesuatu peristiwa yang terkenal (ma'ruf) untuk suatu peristiwa yang tidak terkenal". ${ }^{55}$

Qarînah syar'iyyah (qânûniyyah), yaitu "Qarînah yang dikeluarkan (ditanggapi syara') dari peristiwa yang terkenal untuk peristiwa yang tidak terkenal". ${ }^{56}$

\footnotetext{
${ }^{52}$ Raihan Rasyid, Hukum Acara Peradilan Agama, 174.

${ }^{53}$ Anshoruddin, Hukum Pembuktian menurut Hukum Acara Islam dan Hukum Positif, 88.

${ }^{54}$ Salam Madkur, Hukum Acara Peradilan Agama, 173.

${ }^{55}$ Teungku M. Hasbi As-Siddiqi, Peradilan dan Hukum Acara Islam, (Semarang: Pustaka Rizki Putra, 1997), 158.

${ }^{56}$ Ibid., 159.
} 


\section{Syarat Diterimanya Persumpsion dalam Hukum Acara Pidana Islam}

Pemakaian qarînah sebagai alat bukti adalah merupakan hal yang masih diperselisihksn oleh Fukaha, sebagaimana bahwasanya undangundang yang khusus menyangkut Mahkamah Syar'iyah tidak menganggap qarînah sebagai alat bukti yang dapat dijadikan dasar putusan, kecuali dalam Undang-Undang No. 78 Tahun 1931, dan sungguh undangundang tersebut dengan anggapannya tentang qarînah sebagai alat bukti, telah dapat melindungi banyak hak-hak dan menjauhkan peradilan dari ruh kebekuan.

Inilah segi yang dilalaikan orang sehingga mereka meninggalkan hukuman had dan menyia-nyiakan hak-hak serta membuat penyelewengpenyeleweng semakin berani menimbulkan kerusakan, dan mereka menjadikan syariat Islam semakin sempit ruang lingkupnya, dan menutup diri mereka dari jalan-jalan yang yang benar untuk menyingkap kebenaran dan melaksanakannya, dan di lain pihak ada orang-orang yang melampaui batas sehingga berakibat keluar dari garis yang telah ditentukan hukumnya oleh Allah dan rasul-Nya, padahal Allah swt mengutus utusan-utusan-Nya dan menurunkan kitab-kitab, adalah agar manusia bertindak adil, maka apabila telah nampak adanya tanda-tanda keadilan itu dengan jalan yang apapun yang diperintahkan oleh-Nya, sedang Allah swt telah menjelaskan di dalam syariat yang diturunkan-Nya tentang jalan-jalan yang dimaksudkannya demi tegaknya keadilan di tengah-tengah kehidupan manusia.

Banyak contoh-contoh yang menunjukkan, bahwa Islam menganggap qarînah sebagai alat bukti, dan bahwa Rasulullah saw menganggap dan menggunakan qarînah sebagai dasar putusannya, dan Rasulullah saw pernah menahan orang dan menghukum tertuduh setelah timbul persangkaan karena tampak tanda-tanda mencurigakan pada diri tertuduh. Dan Amirul Mukminin beserta sahabat yang bersamanya pernah menjatuhkan hukuman had atas wanita yang nampak hamil sedangkan ia tidak bersuami dan tidak bertuan. Seperti yang dilakukan Ibnul Qayyim, bahwa qarînah sebagai alat bukti adalah sama dengan kedudukan saksi.

Inilah satu kenyataan kedudukan qarînah dalam fikih Islam. Selain alat-alat bukti yang sudah diterangkan, ada satu alat pembuktian lagi, yaitu qarînah qath'iyyah (qarînah yang meyakinkan). Al-Majallah al-Ahkâm al- 
'Adliyyah seperti yang dikutip oleh Teungku M. Hasbi As-Siddiqi mempergunakan qarînah sebagai bukti. ${ }^{57}$

Hendaknya hakim-hakim yang cerdas dan penguasa-penguasa pemerintahan dapat membebaskan hak-hak yang terampas dengan memperhatikan qarînah-qarînah dan tanda-tanda, apabila qarînah dan tanda-tanda itu jelas adanya maka mereka tidak lagi meminta bukti kesaksian dan juga tidak diminta suatu pengakuan sehingga barulah qarînah bisa dijadikan sebagai dasar untuk menjatuhkan putusan. ${ }^{58}$

\section{Definisi Pembuktian}

Seperti diketahui, dalam pembuktian tidaklah mungkin dapat tercapai kebenaran mutlak (absolut). Semua pengetahuan kita hanya bersifat relatif yang didasarkan pada pengalaman, penglihatan dan pemikiran yang tidak selalu benar..$^{59}$

Pembuktian tentang benar tidaknya terdakwa melakukan perbuatan yang di dakwakan merupakan bagian yang terpenting dalam acara pidana. Dalam hal inipun hak asasi dipertaruhkan. Bagaimana akibatnya jika seseorang yang didakwa dinyatakan terbukti melakukan perbuatan yang didakwakan berdasarkan alat bukti yang ada disertai keyakinan hakim, padahal tidak benar. Untuk itulah maka hukum acara pidana bertujuan untuk mencari kebenaran materiil. ${ }^{60}$

Mencari kebenaran materiil itu tidaklah mudah. Alat-alat bukti yang tersedia menurut undang-undang sangat relatif. Alat-alat bukti sepeti kesaksian menjadi kabur dan sangat relatif. Kesaksian diberikan oleh manusia yang mempunyai sifat pelupa bahkan menurut psikologi, penyaksian suatu peristiwa yang baru saja terjadi oleh beberapa orang akan berbeda-beda. ${ }^{61}$

Pembuktian merupakan masalah yang memegang peranan dalam proses pemeriksaan sidang pengadilan. Melalui pembuktian ditentukan nasib terdakwa. Apabila hasil pembuktian dengan alat-alat bukti yang ditentukan undang-undang tidak cukup membuktikan kesalahan yang didakwakan pada terdakwa, terdakwa dibebaskan dari hukuman. Sebaliknya, kalau kesalahan terdakwa dapat dibuktikan dengan alat-alat

\footnotetext{
${ }^{57} \mathrm{lbid} ., 157$.

${ }^{58}$ Salam Madkur, Peradilan dalam Islam, 123.

${ }^{59}$ Djoko Prakoso, Alat Bukti dan Kekuatan Pembuktian di Dalam Proses Pidana, (Jogjakarta: Liberty, 1988), 37.

${ }^{60}$ Andi Hamzah, Hukum Acara Pidana Indonesia, 249.

${ }^{61}$ Ibid., 250.
} 
bukti yang disebut dalam pasal 184 KUHAP, terdakwa dinyatakan bersalah, kepadanya akan dijatuhkan hukuman. ${ }^{62}$

Pembuktian adalah suatu proses bagaimana alat-alat bukti tersebut dipergunakan, diajukan ataupun dipertahankan sesuai hukum acara yang berlaku. ${ }^{63}$ Sedangkan menurut Yahya Harahap, pembuktian adalah ketentuan-ketentuan yang berisi penggarisan dan pedoman tentang caracara yang dibenarkan undang-undang untuk membuktikan kesalahan yang didakwakan kepada terdakwa.

Pembuktian merupakan titik sentral pemeriksaan perkara dalam bidang pengadilan. Pembuktian adalah ketentuan-ketentuan yang berisi penggarisan dan pedoman tentang cara-cara yang dibenarkan undangundang yang boleh dipergunakan hakim untuk membuktikan kesalahan yang didakwakan. Persidangan pengadilan tidak boleh sesuka hati dan semena-mena membuktikan kesalahan terdakwa. ${ }^{64}$

Berkaitan dengan hal di atas dalam perkara pidana dikenal istilah barang bukti. Menurut Subekti, bukti adalah sesuatu untuk meyakinkan akan kebenaran suatu dalil atau pendirian. Alat bukti, alat pembuktian, upaya pembuktian, adalah alat-alat yang dipergunakan untuk dipakai membuktikan dalil-dalil suatu pihak dimuka pengadilan.

Dari segi Hukum Acara Pidana, tentu saja banyak pendapat tentang arti pembuktian. Disini, dikemukakan salah satu pendapat ahli hukum yang sekaligus praktisi yakni M. Yahya Harahap dalam garis besarnya dikemukakan tentang arti pembuktian, antara lain:

1. Ketentuan yang membatasi sidang pengadilan dalam usahanya mencari dan mempertahankan kebenaran, baik hakim, penuntut umum, terdakwa, atau penasehat hukum, masing-masing terikat pada ketentuan tata cara dan penilaian alat bukti yang ditentukan UndangUndang.

2. Majelis hakim dalam mencari dan menegakkan kebenaran yang akan dijatuhkannya dalam putusan, harus berdasarkan alat-alat bukti yang telah ditentukan undang-undang secara limitatif sebagaimana yang dimaksud dalam pasal 184 KUHAP. ${ }^{65}$

Yang dimaksud dengan alat-alat bukti yang ditentukan oleh undang-undang secara limitatif berdasar pasal 184 KUHAP tersebut ialah

\footnotetext{
${ }^{62}$ Yahya Harahap, Pembahasan Permasalahan dan Penerapan KUHAP, 252.

${ }^{63}$ Bambang Waluyo, Sistem Pembuktian dalam Peradilan di Indonesia, 3.

${ }^{64}$ Yahya Harahap, Pembahasan Permasalahan dan Penerapan KUHAP, 252.

${ }^{65}$ Bambang Waluyo, Sistem Pembuktian dalam Peradilan di Indonesia, 5.
} 
bahwasanya alat-alat bukti yang sah yang dimaksud meliputi keterangan saksi, keterangan ahli, surat, petunjuk, dan keterangan terdakwa.

\section{Sistem Pembuktian}

Di dalam KUHAP cukup jelas dinyatakan tentang jenis-jenis sistem pembuktian yang mana terbagi menjadi 4 macam yang diuraikan sebagai berikut:

1. Conviction in time (pembuktian berdasarkan keyakinan hakim)

System pembuktian Conviction in time semata-mata ditentukan oleh penilaian "keyakinan" hakim. Keyakinan hakim yang menentukan keterbuktian kesalahan terdakwa. Dari mana hakim menarik dan menyimpulkan keyakinannya tidak menjadi masalah dalam sistem ini. ${ }^{66}$ Keyakinan boleh diambil dan disimpulkan hakim dari alat-alat bukti yang diperiksanya dalam sidang pengadilan. Bisa juga hasil pemeriksaan alatalat bukti itu diabaikan hakim dan langsung menarik keyakinan dari keterangan atau pengakuan terdakwa. ${ }^{67}$

Sistem ini memberikan kebebasan kepada hakim terlalu besar, sehingga sulit diawasi. Di samping itu terdakwa atau penasehat hukumnya sulit untuk melakukan pembelaan. Dalam hal ini hakim dapat memidana terdakwa berdasar keyakinannya bahwa ia telah melakukan apa yang didakwakan.

Putusan diserahkan kepada kebijaksanaan hakim walaupun hakim secara logika mempunyai alasan-alasan tetapi hakim tersebut tidak diwajibkan menyebutkan alasan-alasan tersebut. ${ }^{68}$

\section{Conviction Raisonee}

Sistem ini dapat dikatakan "keyakinan hakim" tetap memegang peranan penting dalam menentukan salah tidaknya terdakwa. Akan tetapi dalam sistem pembuktian ini faktor keyakinan hakim dibatasi dalam arti keyakinan hakim harus didukung dengan alasan-alasan yang jelas. Hakim wajib menguraikan dan menjelaskan alasan-alasan apa yang mendasari keyakinannya atas kesalahan terdakwa. ${ }^{69}$ Menurut Andi Hamzah, sistem atau teori pembuktian ini disebut juga pembuktian bebas karena hakim bebas untuk menyebut alasan-alasan keyakinannya. ${ }^{70}$

\footnotetext{
${ }^{66}$ Andi Hamzah, Hukum Acara Pidana Indonesia, 248.

${ }^{67}$ Yahya Harahap, Pembahasan Permasalahan dan Penerapan KUHAP, 256.

${ }^{68}$ Leden Marpaung, Proses Penanganan Perkara Pidana, (Jakarta: Sinar Grafika, 1992), 30.

${ }^{69}$ Yahya Harahap, Pembahasan Permasalahan dan Penerapan KUHAP, 256.

${ }^{70}$ Andi Hamzah, Hukum Acara Pidana Indonesia, 253.
} 


\section{Menurut Undang-Undang secara positif}

Pembuktian menurut Undang-Undang secara positif merupakan pembuktian yang bertolak belakang dengan sistem pembuktian menurut keyakinan hakim. Dalam pembuktian ini keyakinan hakim tidak ikut ambil bagian dalam membuktikan kesalahan terdakwa. Sistem ini berpedoman pada prinsip pembuktian dengan alat-alat bukti yang ditentukan. Untuk membuktikan salah atau tidaknya terdakwa sematamata digantungkan pada alat-alat bukti yang sah asal sudah dipenuhi syarat-syarat dan ketentuan pembuktian menurut undang-undang maka sudah cukup menentukan kesalahan terdakwa tanpa mempersoalkan keyakinan hakim. ${ }^{71}$

Menurut Andi Hamzah dikatakan secara positif karena hanya didasarkan pada undang-undang melulu. Artinya jika telah terbukti suatu perbuatan sesuai dengan alat-alat bukti yang disebut oleh undang-undang, maka keyakinan hakim tidak diperlukan sama sekali. ${ }^{72}$

4. Menurut undang-undang secara negatif

Sistem ini merupakan teori gabungan antara sistem pembuktian menurut undang-undang dengan sistem pembuktian menurut keyakinan hakim. Untuk mentukan salah atau tidaknya terdakwa menurut sistem ini terdapat 2 komponen:

a. Pembuktian harus dilakukan menurut cara dan dengan alat-alat bukti yang sah menurut undang-undang.

b. Dan keyakinan hakim yang ada harus didasarkan atas cara dan dengan alat-alat bukti yang sah menurut undang-undang.

Dengan demikian, sistem ini memadukan unsur obyektif dan subyektif dalam menentukan salah tidaknya terdakwa. ${ }^{73}$

HIR maupun KUHAP semuanya menganut sistem atau teori pembuktian berdasarkan undang-undang secara negatif. Hal ini dapat disimpulkan dari penjelasan pasal 183 KUHAP yang berbunyi sebagai berikut:

"Hakim tidak boleh menjatuhkan pidana pada seseorang kecuali apabila dengan sekurang-kurangnya dua alat bukti yang sah ia memperoleh keyakinan bahwa suatu tindak pidana benar-benar terjadi dan bahwa terdakwalah yang bersalah melakukannya" ${ }^{74}$

\footnotetext{
${ }^{71}$ Yahya Harahap, Pembahasan Permasalahan dan Penerapan KUHAP, 257.

${ }^{72}$ Andi Hamzah, Hukum Acara Pidana Indonesia, 257.

${ }^{73}$ Yahya Harahap, Pembahasan Permasalahan dan Penerapan KUHAP, 258.

${ }^{74}$ Andi Hamzah, Hukum Acara Pidana Indonesia, 254.
} 


\section{Syarat Diterimanya Persumpsion dalam Hukum Acara Pidana}

Di dalam praktik peradilan, sering kali terdapat kesulitan dalam menerapkan alat bukti persumpsion (petunjuk) secara konkrit. Kekurang hati-hatian mempergunakannya, putusan yang bersangkutan bisa mengambang pertimbangannya dalam suatu keadaan yang samar, akibat putusan itu lebih dekat kepada sifat penerapan hukum secara sewenangwenang karena putusan tersebut didominasi oleh nilai yang subyektif yang berlebihan. Untuk menghindari dominasi subyektif hakim yang tidak wajar, mendorong pembuat undang-undang sedini mungkin memperingatkan hakim supaya penerapan dan penilaian alat bukti persumpsion (petunjuk) dilakukan hakim:

1. Dengan arif bijaksana

2. Serta harus lebih dulu mengadakan pemeriksaan dengan penuh kecermatan dan keseksamaan berdasarkan hati nuraninya. ${ }^{75}$

Di samping hakim diajak dan diperingati menarik petunjuk dengan arif dan bijaksana serta harus lebih dulu mengadakan pemeriksaan dengan penuh kecermatan dan seksama berdasarkan hati nuraninya, pasal 188 ayat 2 "membatasi" kewenagan hakim dalam cara memperoleh alat bukti petunjuk. Hakim tidak boleh sesuka hati mencari petunjuk dari segala sumber. Sumber yang dapat digunakan mengkontruksi alat bukti petunjuk terbatas dari alat-alat bukti yang secara "limitatif" ditentukan dalam pasal 188 ayat 2 yakni petunjuk hanya dapat diperoleh dari:

1. Keterangan saksi

2. Surat

3. Keterangan terdakwa. ${ }^{76}$

Persumpsion (petunjuk) tidak mempunyai wadah sendiri, bentuknya sebagai alat bukti adalah "accessor" (tergantung) pada alat bukti keterangan saksi, surat, keterangan terdakwa sebagai sumber yang melahirkannya dan hanya boleh diambil dan diperoleh dari ketiga alat bukti yang lain tersebut. Maka alat bukti persumpsion (petunjuk) baru dapat digunakan jika:

1. Alat bukti yang lain belum dianggap hakim cukup membuktikan kesalahan terdakwa. Atau dengan kata lain alat bukti petunjuk baru dianggap mendesak mempergunakannya apabila pembuktian dengan alat bukti yang lain belum mencapai batas minimum pembuktian.

\footnotetext{
${ }^{75}$ Yahya Harahap, Pembahasan Permasalahan dan Penerapan KUHAP, 241.

76 Ibid., 244.
} 
2. Dengan demikian upaya mempergunakan alat bukti persumpsion (petunjuk) baru diperlukan pada tingkat keadaan daya upaya pembuktian sudah tidak mungkin diperoleh lagi dari alat bukti yang lain. Dalam batas tingkat keadaan demikianlah upaya pembuktian dengan alat bukti persumpsion (petunjuk) diperlukan. ${ }^{77}$

\section{Analisis Kekuatan Hukum Persumpsion dalam Kitab Hukum Acara Pidana dan Hukum Acara Pidana Islam}

Di dalam lingkaran hidup bersama yang kita namakan masyarakat, manusia hidup berdamping-dampingan. Setiap orang mempunyai citacita, keinginan, kebutuhan, alam pikiran dan daya usaha, pendek kata mempunyai kompleks kepentingan-kepentingan hidup. Guna menyelamatkan dan melindungi berbagai kepentingan yang bermacam ragam itu dan memelihara keselarasan hidup di dalam masyarakat timbullah rupa-rupa ketentuan dan peraturan yang menjadi pegangan bagi kehidupan masyarakat. Ketentuan-ketentuan dan peraturan itu berisi petunjuk-petunjuk bagaimana orang harus berbuat, apa yang diwajibkan dan apa yang tidak diperbolehkan agar terpelihara suatu susunan hidup di dalam masyarakat yang harmonis, dimana kepentingan-kepentingan yang bermacam ragam itu satu dengan yang lain dapat disesuaikan setidaktidaknya dapat dijaga atau dihindarkan dari pertentangan-pertentangan yang dapat mengganggu keselarasan hidup di dalam masyarakat dengan mengadakan saluran-saluran tertentu guna penyelesaiannya. ${ }^{78}$

Sifat hubungan antara manusia dengan lingkungan masyarakat pada umumnya adalah timbal balik, artinya orang seorang itu sebagai anggota masyarakat mempunyai hak dan kewajiban, baik terhadap masyarakat maupun terhadap pemerintah dan negara. Beberapa hak dan kewajiban penting ditetapkan dalam Undang-Undang sebagai hak dan kewajiban asasil. Untuk dapat melaksanakan hak dan kewajiban ini dengan bebas dari rasa takut perlu adanya jaminan,dan yang mampu memberikan ini adalah pemerintah yang kuat dan berwibawa. Didalam susunan negara modern, hak-hak dan kewajiban asasi manusia itu dilindungi oleh Undang-Undang dan menjadi hukum positif. Undang-Undang tersebut berlaku sama pada setiap orang tanpa kecuali, dalam arti semua orang mempunyai kesamaan derajat dimata hukum. ${ }^{79}$

\footnotetext{
${ }^{77} \mathrm{Ibid} ., 246$.

${ }^{78}$ R. Tresna, Asas-Asas Hukum Pidana, (Jogjakarta: UNPAD, 1994), 10.

${ }^{79}$ Abu Ahmadi, Ilmu Sosial Dasar, (Jakarta: Rineka Cipta, 1991), 206-207.
} 
Dalam hukum acara pidana Islam, persumpsion bisa dijadikan sebagai alat bukti akan tetapi harus didasari oleh tanda-tanda yang merupakan hasil kesimpulan hakim dalam menangani berbagai kasus melalui ijtihad, tanda-tanda tersebut haruslah dapat menimbulkan keyakinan. Qarînah-qarînah itu terbagi menjadi dua yaitu:

a. Qarînah qânûniyyah, yakni qarînah yang ditentukan oleh undangundang.

b. Qarînah qadhâiyyah, yakni qarînah yang merupakan kesimpulan hakim setelah memeriksa perkara.

Meskipun qarînah merupakan alat bukti namun tidak semua qarînah dapat dijadikan sebagai alat bukti. Kriteria qarînah yang dapat digunakan sebagai alat bukti itu harus jelas dan meyakinkan serta tidak akan dibantah lagi oleh manusia normal. Qarînah yang demikian merupakan qarînah wâdhihah atau qarînah qath'iyyah yang dapat dijadikan dasar pemutus hukum walau hanya atas satu qarînah wâdhihah saja.

Contoh konkrit mengenai qarînah wâdhihah adalah sebagai berikut:

a. Kasus Nabi Yusuf dan Zulaikhah yang terdapat dalam QS. Yusuf ayat 26 dan 27 sebagaimana yang telah disebutkan bahwasanya Zulaikhah menuduh Yusuf a.s. dan mengusulkan kepada suaminya agar dia dijatuhi hukuman yang berat. Ketika pertama kali mereka ditemukan oleh suami dari Zulaikhah namun Yusuf tidak menuduh atau menjelekkan Zulaikhah demi menghormati suaminya. Akan tetapi setelah Yusuf dituduh, maka barulah ia membela diri seraya berkata tanpa berteriak bahwa dia tidak pernah bermaksud buruk kepada Zulaikhah. Dalam kebingungannya itu tampillah saksi dari keluarga Zulaikhah yang memberi kesaksian, dia berkata: jika melihat bajunya koyak di muka, maka wanita itu telah berkata benar bahwasanya Yusuf mempunyai niat jelek kepadanya.

Kapan benarnya ucapan seseorang belum tentu membuktikan kesalahan, maka segera saksi itu meneruskan "dan jika demikian itu halnya maka Yusuf berbohong bahkan ia termasuk kelompok para pendusta". Karena sobeknya baju dari depan itu menunjukkan bahwa Yusuf berhadapan untuk melecehkan wanita itu tetapi Zulaikhah menolak sehingga merobek bajunya. Namun apabila sobeknya baju itu dari belakang maka Yusuf adalah termasuk orang yang benar karena 
Yusuf lari menghindar dari kejaran Siti Zulaikhah dari keterangan di atas dapatlah disimpulkan bahwasanya terdapat qarînah yang menyatakan bahwasanya memang Yusuflah yang benar sehingga keputusan hukum dapat dijatuhkan.

b. Nabi Muhammad pernah menggunakan qarînah yaitu memberikan barang hilang yang diketemukan kepada orang yang dapat menyebutkan sifat-sifat pokok dari barangnya itu.

Dalam hukum acara pidana Islam, yang dikedepankan adalah asas keadilan yang mana asas ini merupakan asas yang penting dan mencakup semua asas dalam bidang hukum Islam.

Menurut pendapat penulis, qarînah itu tetap dijadikan sebagai bukti dan bisa dijadikan alat pembuktian yang langsung jika tidak ada lagi bukti yang lain.

Tidak ragu lagi bahwa seorang hakim diperbolehkan memutuskan semua perkara hukum berdasarkan pengetahuan atau penglihatannya karena kesaksian dua orang saksi itu telah sampai ke tingkat pengetahuan yang betul-betul diperoleh dari kesaksiannya itu. Imam Bukhari menyatakan: Orang yang berpendapat bahwa seorang hakim boleh memutuskan perkara hukum berdasarkan pengetahuan tentang urusan hukum. Jika dia tidak kuatir keputusannya itu sekedar sangkaan dan tuduhan karena Nabi bersabda kepada Hindun:

"Ambillah olehmu apa yang kiranya cukup bagimu dan bagi anakmu (dari harta Abu Sufyan) dengan cara yang baik". ${ }^{80}$

Seiring dengan kemajuan budaya dan IPTEK, perilaku manusia di dalam hidup bermasyarakat dan bernegara justru semakin kompleks dan bahkan multi kompleks. Perilaku demikian apabila ditinjau dari segi hukum tentunya ada perilaku yang dapat dikategorikan sesuai dengan norma dan ada perilaku yang tidak sesuai dengan norma. Terhadap perilaku yang sesuai dengan norma (hukum) yang berlaku, tidak menjadi masalah. Terhadap perilaku yang tidak sesuai dengan norma biasanya dapat menimbulkan permasalahan di bidang hukum dan merugikan masyarakat.

Perilaku yang tidak sesuai dengan norma atau dapat disebut sebagai penyelewengan terhadap norma yang telah disepakati ternyata menyebabkan terganggunya ketertiban dan ketentraman kehidupan manusia. Penyelewengan yang demikian biasanya oleh masyarakat dicap

${ }^{80}$ Al-Asqalaniy, Nail al-Authâr, (Surabaya; Bina Ilmu, 1993), 320. 
sebagai suatu pelanggaran dan bahkan sebagai suatu kejahatan. Kejahatan dalam kehidupan manusia merupakan gejala sosial yang akan selalu dihadapi oleh setiap manusia, masyarakat bahkan negara.Kenyataan telah membuktikan bahwa kejahatan hanya dapat dicegah dan dikurangi tetapi sulit diberantas secara tuntas. ${ }^{81}$

Antisipasi atas kejahatan tersebut diantaranya dengan memfungsikan instrumen hukum (pidana) secara efektif melalui penegakan hukum (law enforcement). Melalui instrumen penegakan hukum diupayakan perilaku yang melanggar hukum ditanggulangi secara preventif maupun represif. Mengajukan ke depan sidang pengadilan dan kemudian penjatuhan pidana bagi anggota masyarakat yang terbukti melakukan perbuatan pidana merupakan tindakan yang represif. Penjatuhan pidana bukan semata-mata sebagai pembalasan dendam, yang paling penting adalah pemberian bimbingan dan pengayoman. ${ }^{82}$

Sehingga dengan demikian, hal yang terpenting di dalam penerapan dan penegakan hukum adalah bukan karena negara atau penguasa mampu melaksanakan dengan kekuasaannya agar suatu peraturan dapat berjalan efektif tetapi adalah peraturan tersebut dibuat untuk kepentingan dan membuat pihak yang lemah menjadi tenteram dan tertib. ${ }^{83}$

Sehubungan dengan adanya peristiwa pidana, maka seorang hakim tidak boleh serta merta menjatuhkan vonis yang kemudian menjatuhkan sanksi pidana yang hanya didasarkan atas penilaian subyektifnya saja. Perbuatan manusia itu barulah dikatakan peristiwa pidana apabila mencukupi segala syarat yang dimuat dalam rumusan dalil hukum yang bersangkutan. Meskipun sesuatu perbuatan pada dasarnya bertentangan dengan ketentuan hukum, akan tetapi jikalau tidak memenuhi segala syarat yang diperlukan, maka perbuatan itu belum tentu dapat dipandang sebagai perstiwa pidana. Sedangkan syarat yang dijadikan pedoman untuk menyatakan bahwa suatu peristiwa bisa dinyatakan sebagai peristiwa pidana adalah sebagai berikut:

a. Harus ada perbuatan manusia

b. Perbuatan itu harus sesuai dengan apa yang dilukiskan di dalam ketentuan hukum.

c. Perbuatan itu harus melawan hukum

\footnotetext{
${ }^{81}$ Andi Hamzah, Hukum Acara Pidana Indonesia, 47.

${ }^{82}$ Bambang Waluyo, Sistem Pembuktian dalam Peradilan di Indonesia, 2-3.

${ }^{83}$ Sidik Sunaryo, Kapita Selekta Sistem Peradilan Pidana, 6.
} 
d. Terhadap perbuatan itu harus tersedia ancaman hukumannya di dalam undang-undang.

Menurut hukum tertulis yang berlaku di indonesia pada umumnya yang dijadikan subyek dari hukum pidana adalah manusia. Meskipun demikian di dalam suatu persidangan seorang hakim tidaklah diperkenankan untuk memberikan putusan pada seseorang tanpa didasarkan atas bukti-bukti yang ada meskipun orang tersebut telah didakwa melakukan suatu tindak pidana dan putusan yang diberikanpun harus didasarkan pada kekuasaan berlakunya undang-undang hukum pidana yang berlaku di Indonesia. Kekuasaan berlakunya undang-undang hukum pidana Indonesia dapat dipandang dari dua sudut:

a. Yang bersifat negatif, yakni berlakunya undang-undang pidana berhubungan dengan waktu. Undang-undang pidana itu tidak berkuasa (berlaku) terhadap sesuatu perbuatan yang dilakukan sebelum undang-undang pidana itu diadakan. Jadi suatu undang-undang pidana itu hanya berlaku untuk masa depannya (datang) dan tidak dapat diberlakukan terhadap perbuatan sebelum diadakannya undangundang pidana itu.

Pendirian itu dengan tegas dinyatakan dalam pasal 1 ayat 1 KUHP yang berbunyi: "Suatu perbuatan tidak dapat dihukum selain atas kekuatan aturan pidana dalam undang-undang yang diadakan sebelum perbuatan itu terjadi".

Hal itu berarti bahwa seseorang hanya dapat dijatuhi hukuman jika perbuatannya itu telah ada atau telah disebut di dalam KUHP. ${ }^{84}$ Dari penjelasan pasal 1 ayat 1 ini dapat ditarik kesimpulan bahwa:

1) Hukum pidana itu mencegah adanya penjatuhan hukuman secara sewenang-wenang oleh pengadilan (hakim).

2) Dapat dicapai kepastian hukum.

3) Hukum pidana itu bersumber pada hukum tertulis.

b. Yang bersifat aktif, yakni berlakunya undang-undang pidana berhubung dengan tempat.

Berangkat dari hal tersebut di atas, maka dalam proses persidangan harus mengedepankan asas praduga tak bersalah. Dengan demikian terlebih dahulu haruslah dilakukan suatu proses pembuktian. Di dalam KUHAP disebutkan bahwasanya proses pembuktian itu tidaklah lepas dari yang namanya alat-alat bukti. Penjelasan tentang alat-alat bukti

${ }^{84}$ Cst. Kansil, Hukum Pidana, (Jakarta: Sinar Grafika, 2007), $28-29$. 
sebagaimana yang tercantum dalam KUHAP pasal 183 adalah sebagai berikut: ${ }^{85}$

1) Keterangan saksi

2) Keterangan ahli

3) Surat

4) Petunjuk

5) Keterangan terdakwa

Berkenaan dengan alat bukti di atas, khususnya alat bukti petunjuk, memang agak sulit untuk menjelaskan pengertian alat bukti petunjuk secara konkrit, bahkan dalam pengadilan pun sering kali mengalami kesulitan untuk menerapkannya. Kekurang hati-hatian mempergunakannya, putusan yang bersangkutan bisa mengambang pertimbangannya dalam suatu keadaan yang samar akibatnya putusan itu lebih dekat kepada sifat penerapan hukum secara sewenang-wenang, karena putusan tersebut didominasi oleh penilaian subyektif yang berlebihan.

Kembali kepada pokok permasalahan. Apa arti dan bagaimana definisi yang tepat tentang alat bukti petunjuk? Sekalipun sulit merumuskan definisinya secara sederhana, dapat menguraikannya bertitik tolak dari bunyi pasal 188 ayat (1). "petunjuk adalah perbuatan maupun dengan tindak pidana itu sendiri, menandakan bahwa telah terjadi tindak pidana dan siapa pelakunya”.

Rumusan pasal itu, agak sulit ditangkap dengan mantap. Barangkali rumusan tersebut dapat dituangkan dengan cara menambah beberapa kata di dalamnya. Dengan "isyarat" yang dapat ditarik dari suatu perbuatan, kejadian atau keadaan dimana isyarat itu mempunyai "persesuaian" antara yang satu dengan yang lain maupun isyarat itu mempunyai persesuaian dengan tindak pidana itu sendiri, dan dari isyarat yang bersesuaian tersebut "melahirkan" atau "mewujudkan" suatu petunjuk yang "membentuk" kenyataan terjadinya suatu tindak pidana dan terdakwalah pelakunya.

Baik dalam rumusan yang diatur dalam pasal 188 ayat (1) maupun dalam rumusan yang disusun, penekanannya terletak pada kata: "persesuaian", yakni adanya persesuaian kejadian, keadaan suatu perbuatan maupun persesuaian dengan tindak pidana itu sendiri. Mari kita ambil contoh untuk lebih mudah memahaminya. A pada tanggal 30

\footnotetext{
${ }^{85}$ Yahya Harahap, Pembahasan Permasalahan dan Penerapan KUHAP, 264-265.
} 
Januari 1984, pergi ke hutan untuk berburu. Kira-kira jam lima sore A melihat rusa serta melepaskan tembakan pada sasaran rusa itu. Ternyata rusa yang ditembaknya lari dan tidak kena. Ia pulang ke rumah. Keesokan harinya seorang petani menemukan mayat B di hutan tempat A kemarin sore berburu. Pada mayat B ditemukan luka tembak di kepala. Menurut istri $\mathrm{B}$, sekitar jam empat tiga puluh menit sore ia meninggalkan B disekitar hutan itu mengambil kayu, dan ia duluan pulang ke rumah karena hari sudah sore. Disamping keterangan istri $\mathrm{B}$ tersebut, saksi $\mathrm{X}$ menerangkan melihat sendiri A disekitar tempat kejadian membawa sepucuk senapan. Sekitar jam lima sore ia mendengar bunyi letusan. Mengenai keterangan saksi X ini A menerangkan bahwa ia benar pada sore itu berburu di sekitar tempat mayat B dijumpai. Dan menerangkan pula, sekita jam lima sore menembakkan senapannya satu kali yang ditujukan kepada seekor rusa, tetapi membantah dia yang membunuh B. Kemudian menurut keterangan ahli kedokteran kehakiman, saat kematian B diperkirakan pula tanggal 30 Januari sekitar jam lima sore. Kematian itu akibat luka tembak di kepala lantas menurut keterangan ahli balistik, luka tembak di kepala B sesuai dengan peluru yang ditembakkan A dari senapannya.

Dalam contoh di atas kita lihat beberapa persesuaian antara perbuatan, kejadian atau keadaan maupun dengan peristiwa pidana yang terjadi. Antara lain adanya persesuaian antara perbuatan A dengan peristiwa pidana yang terjadi, yaitu peristiwa pidana yang mengakibatkan hilangnya nyawa B karena akibat luka tembak dikepala yang dilakukan A. Perbuatan penembakan mana diakui A sekalipun bukan ditujukan kepala $\mathrm{B}$ tapi ditujukan untuk menembak rusa. Juga terdapat persesuaian beberapa kejadian dan keadaan berdasar keterangan istri B dan saksi X. Istri B menerangkan ia meninggalkan suaminya disekitar tempat kejadian kira-kira jam setelah lima sore. Ia meninggalkan suaminya di tempat itu sedang mengambil kayu api. Persesuaian kejadian dan keadaan antara perbuatan, maupun dengan keadaan ialah keterangan $\mathrm{X}$ yang melihat $\mathrm{A}$ sedang berada di sekitar tempat kejadian sedang menyandang senapan dan tiada beberapa lama ia mendengar bunyi letusan sebanyak satu kali. Tapi $\mathrm{X}$ tidak menghiraukan hal itu karena telah mengenal A sebagai pemburu. Kalau diteliti contoh di atas, jelas tampak beberapa isyarat yang memperlihatkan adanya persesuaian perbuatan dengan kejadian atau persesuaian keadaan antara yang satu dengan yang lain. Maupun 
persesuaian dengan tindak pidana itu sendiri. Persesuaian pertama dapat dilihat antara perbuatan A dengan peristiwa pidana hilangnya nyawa $\mathrm{B}$. Perbuatan itu ialah tembakan yang dilakukan A. Kemudian persesuaian antara perbuatan dengan kejadian dan perbuatan, yakni kejadian terjadi sekita jam lima sore sesuai dengan penembakan yang dilakukan A pada sekitar jam lima sore dan istri B berpisah dengan suaminya ditempat kejadian sekitar jam setengah lima. Hal ini sesuai pula dengan keterangan saksi X melihat A di sekitar tempat itu jam lima sore menyandang senapan, dan tiada berapa lama kemudian mendengar bunyi letusan satu kali. Kejadian, keadaan atau perbuatan tersebut bersesuaian pula dengan keterangan A sendiri, pada tanggal dan jam yang disebutkan benar berada di sekitar tempat terjadinya peristiwa pidana. Ia berada di sana untuk berburu rusa dan pada saat melihat rusa ia melepaskan tembakan satu kali. Dalam contoh ini jelas dilihat terdapat beberapa persesuaian antara kejadian dengan perbuatan maupun dengan peristiwa pidana yang terjadi. Semua persesuaian tersebut menjadi petunjuk yang "mewujudkan suatu kerangka yang utuh "tentang peristiwa pidana yang terjadi pada tanggal 30 Januari 1984, sekitar jam lima sore yang pelakunya tiada lain daripada si A, karena kealpaannya telah mengakibatkan hilangnya nyawa $\mathrm{B}$.

Penulis beranggapan bahwa contoh yang dikemukakan tadi agak mudah untuk menemukan dan mengkonstruksi persesuaian antara perbuatan, kejadian, atau keadaan maupun dengan peristiwa itu sendiri. Tentu dalam kenyataan tidak semudah itu membangun suatu persesuaian di antara unsur-unsur tersebut. Namun demikian, dari contoh itu dapat membantu kita memahami pengertian dan cara penerapan alat bukti petunjuk yang diatur dalam pasal 188 ayat (1).

Peringatan yang disampaikan dalam pasal 188 ayat 3 harus benarbenar dipedomani oleh hakim, apabila hakim hendak menggunakan alat bukti petunjuk sebagai dasar penilaian pembuktian kesalahan terdakwa, undang-undang sungguh menuntut kesadaran tanggung jawab hati nurani hakim. Tuntutan tanggung jawab hati nurani itu memperingatkan agar hakim bersikap arif dan bijaksana, tidak sembrono, dan sewenangwenang, maka harus lebih dulu dengan teliti mengadakan pemeriksaan yang menyeluruh secara cermat dan seksama.

Peringatan yang digariskan dalam pasal 188 ayat 3 merupakan "ajakan" kepada hakim agar sedapat mungkin "lebih baik menghindari" penggunaan alat bukti petunjuk dalam penilaian pembuktian kesalahan 
terdakwa. Hanya dalam keadaan yang sangat penting dan mendesak sekali alat bukti ini dipergunakan. Hakim lebih dulu benar-benar memeriksa dan mempergunakan alat bukti yang lain. Selama alat bukti yang lain masih mencukupi, hakim jangan segera berpaling kepada alat bukti petunjuk. Kalau sudah diusahakan memeriksa alat bukti yang lain sampai pada batas maksimal, namun pembuktian belum mencukupi barulah boleh berpaling pada alat bukti petunjuk tetapi jangan cepat berputus asa sebaiknya hakim mencoba berkonsultasi dengan penuntut umum untuk mengusahakan alat bukti tambahan.

Di samping hakim diajak dan diperingati menarik petunjuk dengan arif dan bijaksana serta harus lebih dulu mengadakan pemeriksaan dengan penuh kecermatan dan seksama berdasarkan hati nuraninya, pasal 188 ayat (2) "membatasi" kewenangan hakim dalam cara memperoleh alat bukti petunjuk. Hakim tidak boleh sesuka hati mencari petunjuk dari segala sumber. Sumber yang dapat dipergunakan mengkonstruksi alat bukti petunjuk terbatas dari alat-alat bukti yang secara limitatif ditentukan dalam pasal 182 ayat (2). Menurut pasal 182 ayat (2), petunjuk hanya dapat diperoleh dari:

a. Keterangan saksi

b. Surat

c. Keterangan terdakwa

Hanya dari ketiga alat bukti itu, bukti petunjuk itu dapat diolah. Dari ketiga sumber inilah persesuaian perbuatan, kejadian atau keadaan dapat dicari dan diwujudkan. Kalau kembali melihat contoh yang dikemukakan, persesuaian itu diambil dan diperoleh dari keterangan istri $\mathrm{B}$, keterangan saksi $\mathrm{X}$ dan dari keterangan $\mathrm{A}$ sendiri maupun dari peristiwa pidana yang terjadi.

Harapan penulis, seandainya hakim akan mempergunakan alat bukti petunjuk dalam pembuktian suatu perkara pidana, harus mampu dan jeli mempertautkan setiap persesuaian yang ditemukan secara objektif dan proporsional. Benar-benar persesuaian-persesuaian itu mampu mewujudkan suatu petunjuk "nyata dan utuh" tentang terjadinya tindak pidana, dan terdakwalah yang bersalah melakukannya.

Sehingga dengan demikian penulis dapat mengambil kesimpulan bahwa sudah barang tentu persumpsion adalah sebagai alat bukti yang sah, dan selamanya diperlukan dalam upaya pembuktian suatu proses pemeriksaan perkara pidana. Inilah prinsip umum yang harus 
dipedomani. Namun dalam kenyataan, tidak demikian halnya. Bagaimanapun baik penuntut umum maupun hakim pasti akan lebih mengutamakan alat bukti yang lain, seperti keterangan saksi pada khususnya. Karena bukankah alat bukti keterangan saksi merupakan alat bukti yang yang paling utama dan paling menentukan dalam upaya pembuktian suatu perkara pidana?. Namun hal ini tergantung pada peristiwa pidana yang bersangkutan. Seperti dalam perkara pemalsuan misalnya, barangkali alat bukti surat akan lebih memegang peranan dalam membuktikan kesalahan terdakwa. Oleh karena itu alat bukti persumpsion pada umumnya baru diperlukan apabila alat bukti yang lain belum mencukupi batas minimum pembuktian yang digariskan pasal pasal 183 . Menurut penulis alat bukti persumpsion baru bisa dipergunakan jika telah ada alat bukti yang lain. Karena alat bukti persumpsion, baru mungkin dicari dan ditemukan jika telah ada alat bukti yang lain, sebab persumpsion sebagai alat bukti, bukanlah alat bukti yang memiliki bentuk "substansi tersendiri". Dia tidak mempunyai wadah sendiri jika dibandingkan dengan alat bukti yang lain seperti alat bukti saksi. Bentuknya sebagai alat bukti adalah "assesor" (tergantung) pada alat bukti keterangan saksi, surat dan keterangan terdakwa sebagai sumber yang yang dapat melahirkannya.

\section{Simpulan}

Kekuatan yuridis persumpsion menurut KUHAP, baru bisa mempunyai kekuatan hukum untuk untuk menjatuhkan putusan jika dikaitkan dengan alat bukti yang lain. Bahwasanya kekuatan yuridis persumpsion menurut Hukum Acara Pidana Islam sudah mempunyai kekuatan hukum untuk menjatuhkan putusan meskipun tanpa didukung oleh alat bukti yang lain.

Persumpsion dalam KUHAP dan Hukum Acara Pidana Islam keduanya mempunyai kesamaan, yakni sama-sama dapat digunakan sebagai alat bukti dan mempunyai kekuatan hukum dalam proses pembuktian. Sedangkan yang membedakan adalah dalam KUHAP berlaku pada pembuktian tidak langsung sedangkan dalam Hukum Acara Pidana Islam berlaku pada pembuktian langsung.

\section{Daftar Rujukan}

Ahmadi, Abu. Ilmu Sosial Dasar. Jakarta: Rineka Cipta, 1991.

Al-Asqalaniy. Nail al-Authâr. Surabaya; Bina Ilmu, 1993. 
Anshoruddin. Hukum Pembuktian menurut Hukum Acara Islam dan Hukum Positif. Yogyakarta: Pustaka Pelajar, 2004.

Arto, Mukti. Praktek Perkara Perdata. Jogjakarta: Pustaka Pelajar, 2003.

As-Siddiqi, Teungku M. Hasbi. Peradilan dan Hukum Acara Islam.

Semarang: Pustaka Rizki Putra, 1997.

Bukhari. Shahih Bukhari. Beirut: Dar al-Fikr, t.t.

Departemen Agama. Al-Qur'an dan Terjemahnya. Surabaya: Al-Hidayah, 2002.

Departemen Pendidikan dan Kebudayaan. Kamus Bahasa Indonesia. Jakarta: Balai Pustaka, 1995.

Hamid, Andi Thahir. Hukum Acara Pidana Umum dan Hukum Acara Pidana Khusus. Surabaya: CV. Al-Ikhsan, 1993.

Hamzah, Andi. dan Irdan Dahlan. KUHAP, HIR dan Komentar. Jakarta: Gholia Indonesia, 1985.

Hamzah, Andi. Hukum Acara Pidana Indonesia. Jakarta: Sinar Grafika, 2005.

. KUHP dan KUHAP. Jakarta: Rineka Cipta, 1992.

Harahap, Yahya. Pembahasan Permasalahan dan Penerapan KUHAP. Jakarta: Sinar Grafika, 2000.

Hidajah, Hidajatul. Peta Pemikiran Sosiologi dan Perkembangannya. Surabaya: Putra Pelajar, 2003.

Kansil, Cst. Hukum Pidana. Jakarta: Sinar Grafika, 2007.

Madkur, Salam. Peradilan dalam Islam. Surabaya: Bina Ilmu, 1993.

Marpaung, Leden. Proses Penanganan Perkara Pidana. Jakarta: Sinar Grafika, 1992.

Mertokusumo, Sudikno. Hukum Acara perdata Indonesia. Jogjakarta: Liberti, 1996.

Mostar, Herman. Peradilan yang Sesat. Jakarta: Pustaka Utama Grafiti, 1987.

Prakoso, Djoko. Alat Bukti dan Kekuatan Pembuktian di dalam Proses Pidana. Jogjakarta: Liberty, 1988.

Quraish Shihab, M. Tafsir Al-Misbah V. 3. Jakarta: Lentera Hati, 2001.

Rasyid, Roihan A. Hukum Acara Peradilan Agama. Jakarta: Raja Grafindo Persada, 1994.

RM, Suharto. Penuntutan dalam Praktek Peradilan. Jakarta: Sinar Grafika, 1997.

Sabiq, Sayyid. Fiqih Sunnah Jilid 3. Beirut: Dar al-Fikr, tt. 
Saleh, Roeslan. Hukum Pidana sebagai Konfrontasi Manusia dan Manusia. Jakarta: Sinar Grafika, 1998.

Soekamto, Soejono. Pokok-Pokok Sosiologi Hukum. Jakarta: Raja Grafindo Persada, 1999.

Subekti, R. Hukum Pembuktian. Jakarta: Pradnya Paramita, 1975.

Sunaryo, Sidik. Kapita Selekta Sistem Peradilan Pidana. Malang: UMM Press, 2004.

Tresna, R. Asas-Asas Hukum Pidana. Jogjakarta: UNPAD, 1994.

Usman, Mukhlis. Kaidah-Kaidah Ushuliyah dan Fiqhiyah. Jakarta: Raja Grafindo Persada, 1999.

Waluyo, Bambang. Sistem Pembuktian dalam Peradilan di Indonesia. Jakarta: Sinar Grafika, 1996. 